\title{
Thiol/Disulphide Homeostasis Neutrophil Lymphocyte and Platelet Lymphocyte Ratio in Emergency Department Patients with Renal Colic
}

\author{
Acil Serviste Renal Koliği Olan Hastalarda Tiyol/Disülfid \\ Homeostazı Nötrofil Lenfosit ve Platelet Lenfosit Oranı
}

\author{
Şervan Gökhan, Çağdaş Yıldırım¹, Gül Pamukçu Günaydın², Gülhan Kurtoğlu Çelik, Fatih Ahmet \\ Kahraman ${ }^{2}$, Fatih Tanrıverdi' ${ }^{1}$ Ayhan Özhasenekler ${ }^{1}$, Özcan Erel${ }^{3}$ \\ ${ }^{1}$ Ankara Yıldırım Beyazıt University, Department of Emergency Medicine \\ ${ }^{2}$ Ankara Ataturk Training and Research Hospital, Department Emergency Medicine \\ ${ }^{3}$ Ankara Yıldırım Beyazıt University, Department of Biochemistry
}

\begin{abstract}
Objectives: This study's aim is to investigate if using thiol/disulphide homeostasis parameters which are oxidative stress markers together with Neutrophile-Lymphocyte and Platelet-Lymphocyte ratio (NLR, PLR) is diagnostically useful in the patients who present to the emergency department with renal colic.

Materials and Methods: The study was made prospectively with 75 patients who were admitted to the emergency department between 15.05.2018 and 01.10.2018 and 47 healthy subjects who were determined as control group. Thiol/disulphide homeostasis parameters (thiol, disulphide, disulphide / native thiol, disulphide / total thiol, native thiol / total thiol) which are oxidative stress markers are measured by a new method which was developed by Erel and Neșelioğlu in the patient and control groups, also NLR and PLR were studied. These parameters were compared also between the patient groups with urinary stone disease and that without.

Results: NLR, PLR, disulphide, disulphide / native thiol and disulphide /total thiol average values were found significantly high (respectively $\mathrm{p}=0.010,<0.001,<0.001,<0.001,0.023,0.012$ ), but native thiol and total thiol average values were found significantly low (respectively $\mathrm{p}=0.018$ and 0.001 ) in the patient group. Disulphide, disulphide /native thiol, NLR and PLR average values were found significantly high (respectively $\mathrm{p}<0.001,<0.001,<0.001,<0.001$ ) in the patient group.

Conclusion: Using NLR and PLR in renal colic diagnosis together with thiol/disulphide homeostasis parameters is useful for these patients to make a diagnosis.

Key words: Renal colic, oxidative stres, thiol/disulphide homeostasis
\end{abstract}

Öz

Amaç: Bu çalışmanın amacı acil servise renal kolik nedeniyle başvuran hastalarda oksidatif stres markerlarından olan tiyol/disülfid homeostazı parametreleri ile Nötrofil-Lenfosit ve Platelet-Lenfosit oranlarının (NLO, PLO) beraber kullanımının tanı açısından yararlı olup olmadığını araştırmaktır.

Materyal ve Metot: Çalışma 15.05.2018 ile 01.10.2018 tarihleri arasında acil servise başvuran ve çalışmaya alınan 75 hasta ve kontrol grubu olarak belirlenen 47 sağlıklı kiși ile prospektif olarak yapıldı. Erel ve Neșelioğlu tarafından yeni geliștirilen bir metot ile oksidatif stres belirteci olan tiyol/disülfid homeostaz parametreleri ( Tiyol, disülfid, disülfid / native tiyol, disüfid / total tiyol, native tiyol / total tiyol) ile NLO ve PLO hasta ve kontrol grubunda çalıșıldı. Üriner taş hastalığı olan ve olmayanlar arasında bu parametreler karşılaștırıldı.

Bulgular: Renal koliği olanlarda kontrol grubuna göre, NLO, PLO, disülfid, disülfid /native tiyol ve disülfid /total tiyol ortalama değerleri anlamlı derecede yüksek bulunurken (sırasıyla $\mathrm{p}=0.010,<0.001$, $<0.001$, <0.001, 0.023, 0.012), native tiyol ve total tiyol ortalama değerleri anlamlı derecede düşük bulundu (sırasıyla $\mathrm{p}=0.018$ ve 0.001 ). Üriner taş hastalığı olan grupta olmayan gruba göre disülfid, disülfid /native tiyol, NLO ve PLO ortalama değerleri anlamlı derecede yüksek bulundu (sırasıyla p $<0.001,<0.001,<0.001$, <0.001).

Sonuç: NLO ve PLO ile tiyol/disülfid homeostaz parametrelerinin renal kolik tanısında beraber kullanılması bu hastalarda tanının konulması açısından faydalıdır.

Anahtar kelimeler: Renal Kolik, oksidatif stres, tiyol/disülfid homeostazı 
Thiol/Disulphide Homeostasis Neutrophil Lymphocyte and Platelet Lymphocyte Ratio in Emergency Department Patients with Renal Colic

Correspondence / Yazıșma Adresi:

Dr. Şervan Gökhan

Ankara Yıldırım Beyazıt University, Department of Emergency Medicine, o68oo, Bilkent / Ankara

e-mail: sgokhan@ybu.edu.tr

Date of submission: 31.10 .2018

Date of admission: 27.11 .2018

\section{Introduction}

Renal colic is one of the important urological emergencies which presents with serious abdominal and flank pain. Renal colic occurs often due to stone disease and may be associated with urinary obstruction. Prevalence of urinary stone disease around the world changes between $2-20 \%{ }^{1,2}$ Although most common reason is urinary stone disease, there are many extrinsic and intrinsic reasons which may cause renal colic symptoms too. Blood clots and sloughed renal papilla (often due to sickle cell disease, analgesic use for longer periods or diabetes mellitus) are among intrinsic reasons and lympodenopathies are among extrinsic reasons. ${ }^{3}$

Character and spread of the pain together with the patient's anamnesis are important in the diagnosis of renal colic. In addition, radiological images are used together with urinary and blood tests. Pain spreading to the groin, testicles, labia majora and flank area is a common complaint of renal colic. If there is obstruction (partial or complete), difficult urination is seen. Nausea is also one of the frequent symptoms in these patients together with pain.3,4 Ultrasonography and non-contrast CT are the most frequently used imaging methods in the emergency departments. Ultrasonography is an inexpensive imaging method which is easily accessible and without radiation exposure. ${ }^{3}$

Reasons such as mucosal injuries, wall strains may cause inflammation during passage of stone, crystal or other factors. This possibly results in inflammatory reactions, especially in the ureter. ${ }^{5}$ Released cytokines and proteolytic enzymes, leukocyte infiltration and the degree of inflammation are important factors in scar formation and renal fibrosis formation. ${ }^{6,7}$

Neutrophile lymphocyte (NLR) and Platelet lymphocyte ratios (PLR) are inexpensive and easily obtainable strong markers of inflammatory response. Especially NLR is a marker which has been studied in many clinical conditions from infections to chronic diseases and it is used as an indicator for systemic inflammations and infections. ${ }^{8-10}$ It is known that, mediators which are released due to oxidative stress cause many systemic diseases presenting with inflammation. Thiol/ disulphide homeostasis parameters are used to determine oxidative stress and they have been measured uni-directionally since 1979. These parameters can be measured nowadays both separately and also collectively by a novel method which was developed by Erel and Neșelioğlu. ${ }^{11,12}$

According to our knowledge there is no prior study which investigates the relation between thiol/ disulphide homeostasis parameters and NLR and PLR in renal colic. The aim of this study is to show if using thiol/ disulphide homeostasis parameters together with NLR and PLR in the patients who are admitted to the emergency department with renal colic is diagnostically useful or not. 
Thiol/Disulphide Homeostasis Neutrophil Lymphocyte and Platelet Lymphocyte Ratio in Emergency Department Patients with Renal Colic

\section{Materials and Methods}

Approval was received from Ankara Yıldırım Beyazıt University Ethics Committee for this study according to the last version of Helsinki declaration. The study was made prospectively with 75 patients who were admitted to Yıldırım Beyazıt University Medical Faculty Atatürk Training and Research Hospital Emergency Department between 15th May 2018 and ist October 2018 and who were followed-up with renal colic. Renal colic is defined as the sudden onset of severe loin pain (in the costovertebral angle) in our study. Ultrasonography was performed as the first line imaging in patients presented with renal colic. If ultrasonography couldn't detect any urinary stones, non-contrast tomography was performed. Urinary stone disease was diagnosed when urinary stone was detected with ultrasonography or non-contrast tomography.

47 healthy subjects who had similar characteristics with the patient group regarding age and gender were determined as control group. In addition patient group was divided into two groups with urinary stone disease and without urinary stone disease. Thiol/ disulphide homeostasis parameters, NLR and PLR values were compared between the groups.

Age, gender, presenting complaint, medical backgrounds, accompanying additional system anomalies and diseases of the patients who were included in the study were registered in the study forms. Symptoms and findings at the time of admission to the emergency department (localization, spread and character of the pain, dysuria, thamuria, urgency, nausea and vomiting) were evaluated. Physical examination findings, laboratory results of blood and urine examination and imaging results were registered on the standard study forms.

Patients with chronic and inflammatory diseases, positive urine culture or urinary tract infection and high fever; patients who use antibiotics, drugs or have substance-use disorders and who had an infection in the last one month were excluded from the study.

Complete blood count and blood samples were taken from each patient in order to study biochemical markers, thiol/disulphide homeostasis parameter (Thiol, disulphide, native thiol, disulphide / native thiol, disulphide / total thiol, native thiol / total thiol) levels. Urine samples were taken in order to make urine microscopy and cultures.

Native thiol, total thiol and disulphide values were measured by using a novel method which was developed by Erel and Neșelioğlu. Disulphide /native thiol, disulphide /total thiol and native thiol/total thiol values were calculated. ${ }^{11}$ NLR and PLR values were calculated too by proportioning neutrophile and lymphocyte values and platelet and lymphocyte values.

Normality analysis was made with Kolmogorov Smirnov Test. Above $\mathrm{P}<0.05$ value was accepted as normally distributed data. Results were given as mean $\pm \mathrm{SD}$ in terms of normally distributed data. Univariate statistical analyses were made by using ChiSquare Test for categorical valuables and by using Student-T Test for continuous variables. $\mathrm{P}<0,05$ value was accepted as statistically significant. IBM SPSS Statistics 21.0 (IBM Corp. released 2012. IBM SPSS Statistics for Windows, version 21.0, Armonk, NY) and MS-Excel 2007 programs were used for statistical analysis/calculations. 
Thiol/Disulphide Homeostasis Neutrophil Lymphocyte and Platelet Lymphocyte Ratio in Emergency Department Patients with Renal Colic

\section{Results}

$55 \%(n=41)$ of patients who were included in the study were male. Mean age of patient group was $38.65 \pm 12.16$ years. $53 \%(n=23)$ of control group was male and $47 \%(n=22)$ was female subjects and average age was $36.81 \pm 9.52$ years. There was no statistically significant difference between the patient group and control group regarding age and gender (respectively $\mathrm{p}=0.352$ and $\mathrm{p}=0.158$ ).

When patient and control groups were compared according to NLR, PLR and thiol/ disulphide homeostasis parameters, NLR, PLR, disulphide, disulphide /native thiol and disulphide /total thiol average values were found significantly high (respectively $\mathrm{p}=$ $0.010,<0.001,<0.001,<0.001,0.023,0.012$ ) in the patient group according to the control group, native thiol and total thiol average values were found significantly low (respectively $\mathrm{p}=0.018$ and $\mathbf{0 . 0 0 1}$ ). PLR, NLR and thiol/ disulphide homeostasis parameters of patient and control group have been shown in Table 1.

Table 1. Comparison of thiol/ disulphide homeostasis parameters and NLR and PLR levels of patient group and control group

\begin{tabular}{|l|c|c|c|}
\hline & $\begin{array}{c}\text { Patient group } \\
(\mathbf{n}=75)\end{array}$ & $\begin{array}{c}\text { Control group } \\
(\mathbf{n}=47)\end{array}$ & $\mathbf{P}$ \\
\hline Native Thiol $(\boldsymbol{\mu m o l} / \mathrm{L})$ & $419.08 \pm 94.90$ & $452.16 \pm 57.12$ & 0.018 \\
\hline Total Thiol $(\boldsymbol{\mu m o l} / \mathbf{L})$ & $457.52 \pm 95.22$ & $503.45 \pm 57.55$ & 0.001 \\
\hline Disulphide $(\boldsymbol{\mu m o l} / \mathbf{L})$ & $26.40 \pm 15.35$ & $16.77 \pm 6.74$ & $<0.001$ \\
\hline Disulphide /native thiol & $0.063 \pm 0.040$ & $0.042 \pm 0.018$ & $<0.001$ \\
\hline Disulphide /total thiol & $0.068 \pm 0.114$ & $0.037 \pm 0.014$ & 0.023 \\
\hline Native thiol/total thiol & $0.915 \pm 0.055$ & $0.898 \pm 0.051$ & 0.093 \\
\hline NLR & $4.06 \pm 2.41$ & $1.53 \pm 0.59$ & $<0.001$ \\
\hline PLR & $125.72 \pm 59.36$ & $103.44 \pm 35.16$ & 0.010 \\
\hline
\end{tabular}

When the patient group is divided in two groups according to having urinary stone disease or not and comparisons regarding to NLR, PLR and thiol/ disulphide homeostasis parameters are made; disulphide, disulphide /native thiol, NLR and PLR average values were found significantly high in patients with urinary stone disease (respectively $\mathrm{p}<0.001,<0.001,<0.001,<0.001$ ). Comparison of thiol/ disulphide homeostasis parameters, PLR and NLR values according to having urinary stone disease or not in the patient group has been shown in Table 2.

\section{Discussion}

Renal colic can be defined as pain due to ureter, pelvicalyceal system or renal capsule obstruction, distention or spasm. It has two peak periods at second decade and between 40-6o years. Its lifelong prevalence is higher in men than in women.,13 In our study, the patients' distribution were compatible with the literature both in terms of age and gender.

Urinary stone disease or other causes leading to renal colic attacks also cause inflammatory changes in the mucosal structures probably, along the urinary tract. 
Thiol/Disulphide Homeostasis Neutrophil Lymphocyte and Platelet Lymphocyte Ratio in Emergency Department Patients with Renal Colic

Even if there are potential explanations regarding inflammation which occurs during this passage, there is no comprehensive study which was made about this subject. Studies on ureteral peristaltism, submucosal edema and ureter wall spasm are found in the literature. ${ }^{2,5,14}$

Table 2. Comparison of thiol/disulphide homeostasis parameters, NLR and PLR values in the patient group with urinary stone disease and without urinary stone disease

\begin{tabular}{|l|c|c|c|}
\hline & $\begin{array}{c}\text { With urinary } \\
\text { stone disease } \\
(\mathbf{n = 5 1})\end{array}$ & $\begin{array}{c}\text { Without urinary } \\
\text { stone disease } \\
(\mathbf{n = 2 4})\end{array}$ & $\mathbf{P}$ \\
\hline Native Thiol $(\boldsymbol{\mu m o l} / \mathbf{L})$ & $410.21 \pm 82.51$ & $432.38 \pm 111.11$ & 0.355 \\
\hline Total Thiol $(\boldsymbol{\mu m o l} / \mathbf{L})$ & $450.24 \pm 86.83$ & $468.45 \pm 107.19$ & 0.441 \\
\hline Disulphide $(\boldsymbol{\mu m o l} / \mathbf{L})$ & $31.97 \pm 14.69$ & $18.05 \pm 12.41$ & $<0.001$ \\
\hline Disulphide /native thiol & $0.076 \pm 0.038$ & $0.042 \pm 0.033$ & $<0.001$ \\
\hline Disulphide /total thiol & $0.068 \pm 0.033$ & $0.069 \pm 0.177$ & 0.965 \\
\hline Native thiol/total thiol & $0.911 \pm 0.055$ & $0.921 \pm 0.054$ & 0.434 \\
\hline NLR & $5.44 \pm 2.09$ & $2.00 \pm 0.91$ & $<0.001$ \\
\hline PLR & $146.99 \pm 65.44$ & $93.83 \pm 27.38$ & $<0.001$ \\
\hline
\end{tabular}

Proinflammatory cytokines increase along with the increase of oxidative stress mediators in many diseases with inflammation. Thiol / disulphide homeostasis is one of the most recent markers of oxidative stress. ${ }^{1,15}$ Thiol/disulphide homeostasis plays a role in signal transduction, enzyme regulation, detoxification and apoptosis. Unbalance of thiol/disulphide plays a role in the formation of many diseases presenting with inflammation (cardiovascular diseases, diabetes mellitus, chronic kidney failure, Alzheimer and Parkinson and cancer). ${ }^{16,17}$ NLR has been studied as diagnostic marker under inflammation in many studies. ${ }^{18,19}$ Studies have been performed with complete blood count in renal colic patients. NLR values have been found significantly high in the patients who are admitted with renal colic according to the control group in the study of Acar et al. PLR values haven't been found significant in the same study. Neutrophil values have been found significantly high in the patients with renal colic and urinary stone disease according to the control group in the study of Sfoungaristos et al. ${ }^{10,20}$ NLR and PLR values were found significantly high in the patients with renal colic in our study. Our results show similarity with studies in the literature regarding NLR in this respect. Disulphide, disulphide/native thiol and disulphide/total thiol average values were found significantly high in patients with renal colic. Native thiol and total thiol average values were found significantly low. This result has been deemed as compatible with studies in literature which show the change in thiol/ disulphide homeostasis parameters in pathologies with infection and inflammation. ${ }^{21}$ Disulphide/native thiol, NLR and PLR average values were found significantly high in the group with urinary stone disease. In this respect, NLR value shows similarity with studies in the literature, but PLR value differs from studies in the literature. ${ }^{10,20}$ In the study of Bozkurt et al. when change in thiol/disulphide 
Thiol/Disulphide Homeostasis Neutrophil Lymphocyte and Platelet Lymphocyte Ratio in Emergency Department Patients with Renal Colic

homeostasis parameters were examined after extracorporeal shockwave lithotripsy treatment, it was detected that disulphide, disulphide /native thiol and disulphide /total thiol values increased 6 hours later after the procedure. However, it was concluded that oxidative stress increased in the acute period of treatment. ${ }^{22}$ We think also that the reason of thiol/disulphide homeostasis change in our study is the increase of oxidative stress in patients with urinary stone disease.

In conclusion, we were not able to find any study in which renal colic and NLR, PLR and Thiol/ disulphide homeostasis were investigated together in the literature. Our study is the first one in this respect. We think that studying thiol/disulphide homeostasis parameters together with NLR and PLR may be diagnostically useful in renal colic diagnosis. more large-scale studies with higher number of cases are needed in this respect.

We think we have a small number of patients and more large-scale studies with higher number of cases are needed in this respect.

\section{References}

1. Duran L, Acar E, Çelenk Y et al. Evaluation of patients presenting with renal colic in emergency. Kocatepe Medical Journal 2014;15:274-8.

2. Picozzi SC, Marenghi C, Casellato $S$ et al. Managment of ureteral calculi and medical expulsive therapy in emergency departments. J Emerg Trauma Shock 2011;4:70-6.

3. Bultitude M and Rees J. Managment of renal colic.BMJ 2012;345:e5499. doi:10.1136/bmj.e5499.

4. Johri N, Cooper B, Robertson W et al. An update and practical guide to renal stone managment. Nephron Clin Pract 2010;116:159-71.

5. Tadayyon F, Yzdani M, Ebadzadeh M. A comparison study between theophylline and placebo in passage of ureteral stones. Urol J 2004;1:204-7

6. Shihamura T. Mechanisms of renal tissue destruction in an experimental acute pyelonephritis. Exp Mol Pathol 1981;34:34-42.

7. Monga M,Roberts JA. The possible role of granulocyte elastase in renal damage from acute pyelonephritis. Pediatr Nephrol 1995;9:583-6.

8. Lowsby R, Gomes C,Jarman I et al. Neutrophile to lymphocyte count ratio as an early indicator of blood stream infection in the emergency department. Emerg Med J 2015;32:531-4

9. Bolat D, Topcu YF, Aydogdu O et al. Neutrophil to lymphocyte ratio as a predictor of early penile prosthesis implant infection. Int Urol Nephrol 2017;49:947-53.

10. Acar E, Ozcan O, Deliktas $\mathrm{H}$ et al. Laboratory markers has many valuable parameters in discrimination between acute appendicitis and renal colic. Ulus Travma Acil Cerrahi Derg 2016;22(1):17-22.

11. Erel O, Neselioglu S. A novel and automated assay for thiol/disulphide homeostasis. Clin Biochem 2014;47:326-32.

12. Ellman G, Lysko H. A precise method for the determination of whole blood and plasma sulfhydryl groups. Anal Biochem 1979;93:98-102.

13. Curhan GC. Epidemiology of stone disease. Urol Clin N Am 2007;34:287-93.

14. Nuss GR, Rackey JD, Assimos DG. Adjunctive therapy to promote stone passage. Rev Urol 2005;7:67-74.

15. Horton JW. Free radicals and lipid peroxidation mediated injury in burn trauma: The role of antioxidant therapy. Toxicology 2003;189(1-2):75-88.

16. Kundi H, Erel Ö, Balun A, Çiçekçioglu H, Cetin M, Kiziltunç E et al. Association of thiol/disulfide ratio with syntax score in patients with NSTEMI. Scand Cardiovasc J 2015;49:95100.

17. Eren Y, Dirik E, Neselioglu S, Erel O. Oxidative stress and decreased thiol level in patients with migraine: cross-sectional study. Acta Neurol Belg 2015;115:643-9. 
Thiol/Disulphide Homeostasis Neutrophil Lymphocyte and Platelet Lymphocyte Ratio in Emergency Department Patients with Renal Colic

18. Peng W, Li C, Wen TF et al. Neutrophile to lymphocyte ratio changes predict small hepatocelluler carcinoma survival. J Surg Res 2014;192:402-8.

19. Bhar T, Teli S, Rijal J et al. Neutrophile to lymphocyte ratio and cardiovascular disease: a review. Expert Rev Cardiovasc Ther 2013;11:55-9.

20. Sfoungaristos S, Kavouras A, Katafigiotis I, Perimenis P. Role of White blood cell and neutrophile counts in predicting spontaneous stone passage in patients with renal colic. BJU International 2012,110:339-45.

21. Parlak ES, Alisik M, Hezer $\mathrm{H}$ et al. Evaluation of dynamic thiol/disulphide redox state in community-acquired pneumonia. Saudi Med J. 2018 May;39(5):495-9.

22. Bozkurt A, Mertoglu C, Karabakan M et al. Does extracorporeal shockwave lithotripsy therapy affect thiol-disulfide homeostasis? Pak J Med Sci 2018;34(5):1070-5 